PREPARED IN COOPERATION WITH THE

STATE OF CONNECTICUT

GEOLOGICAL AND NATURAL HISTORY SURVEY

\title{
AEROMAGNETIC MAP OF PARTS OF THE NIANTIC AND NEW LONDON QUADRANGLES, NEW LONDON COUNTY, CONNECTICUT
}

GEOPHYSICAL INVESTIGATIONS

MAP GP-879

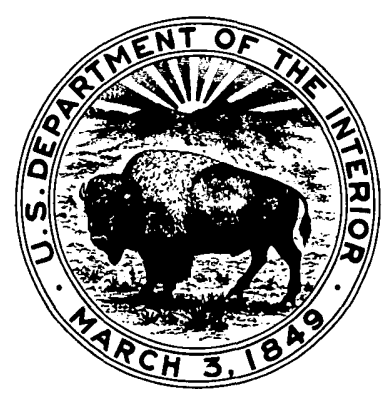

PUBLISHED BY THE U.S. GEOLOGICAL SURVEY 